\title{
The Concentration of Haemoglobin in the Blood of Young Adult Men and Women: the Effect of Administering Small Doses of Iron for Prolonged Periods
}

\author{
By R. C. GARRY, A. W. SLOAN, J. B. DE V. WEIR \\ AND MARY WISHART \\ Institute of Physiology, University of Glasgow \\ (Received 4 Fanuary 1954)
}

We now realize that individual values, obtained while observing apparently healthy animals, may deviate appreciably from the mean of such values and still, so far as we can tell, be compatible with health. Values that deviate considerably from the mean may nevertheless be 'normal'. Values for the concentration of haemoglobin in the blood belong to this category and pose rather special problems of their own. Here we are dealing with two variables, the mass of the haemoglobin and the volume of the plasma, and these may vary independently. The reading obtained in conventional haemoglobinometry is a function of both. Whitby (195I) discusses this problem fully.

The accepted 'normal' value for the concentration of haemoglobin in human blood has increased progressively with the passage of years. Whereas $13.8 \mathrm{~g} / \mathrm{roo} \mathrm{ml}$. blood was ' $100 \%$ ' for Haldane's original twelve healthy men, something approaching $\mathrm{r} 6 \mathrm{~g} / \mathrm{ro0} \mathrm{ml}$. blood is now thought to be the desirable concentration in men. But the concentration in the blood of apparently healthy adult women, even when all factors other than sex are comparable, has obstinately lagged behind, so that something of the order of $\mathrm{I} 4 \mathrm{~g}$ haemoglobin/100 ml. blood is accepted as normal for them (Osgood, I926; Price-Jones, I93I ; Osgood, Haskins \& Trotman, 1931-2; Jenkins \& Don, I933; Wintrobe, 1933; Sunderman \& Boerner, I949; Whitby, 195 I; Berry, Cowin \& Magee, I952).

Until the age of puberty the concentration of haemoglobin in the blood of healthy boys and girls is the same (Williamson, 1916). From puberty to menopause the 'normal' concentration of haemoglobin in the blood of apparently healthy women is less than the 'normal' concentration in the blood of men. After the menopause the values for women approximate to, but never quite reach, the values for men of the same age. Adult civilized men and women form two distinct 'populations', in a statistical sense, with respect to the concentration of haemoglobin in their blood, although there is very considerable overlap. It should be noted, however, that histograms of the values for women in general are skew, owing to a large number of low values (Milam \& Muench, 1946). Davies, Levin \& Oberholzer (1952) have recently pointed out that the concentration of iron in the serum of women is lower than that in the serum of men, although the iron-binding capacity of the serum is the same. Whatever the explanation, these observed differences between men and women are undoubtedly associated with the period of female sexual activity. 
There is an obvious possible explanation of these observations. Civilized women, living on the typical diet of civilization, may find difficulty in replacing the iron lost in menstruation or in child-bearing. Balfour, Hahn, Bale, Pommerenke \& Whipple (1942) say: 'It is reasonably certain that the healthy adult woman must absorb more iron than the healthy male... and she must replace the menstrual hemoglobin loss which averages 6 to $9 \mathrm{gm}$. hemoglobin or 20 to $30 \mathrm{mg}$. Fe per month.' The losses of iron in menstruation may be considerably more than this (Gillett, Wheeler \& Yates, 1918-19; Ohlson \& Daum, 1935; Barer \& Fowler, 1936). The work of Davidson and his co-workers (Davidson, Fullerton, Howie, Croll, Orr \& Godden, 1933; Davidson, Donaldson, Lindsay \& McSorley, 1943) shows that iron-deficiency anaemia, abnormal by any standard, is all too prevalent among women of child-bearing age. The special report on the comprehensive survey by the Medical Research Council: Committee on Haemoglobin Surveys (1945) tells the same tale. On the other hand, men rarely show a gross hypochromic anaemia. Is it possible, then, that apparently healthy women 'normally' suffer from a mild degree of iron-deficiency anaemia?

Administration of large doses of iron preparations will restore the concentration of haemoglobin in the blood of frankly anaemic women to the 'normal' for women. Can such treatment, however, raise the 'normal' for women to the 'normal' for men? Widdowson \& McCance (1936) gave $100 \mathrm{mg}$ iron daily to fifteen men and to sixteen women. The administration lasted for only from 2 to 4 weeks. The concentration of haemoglobin in the blood of the men rose but slightly, whereas that in the blood of the women rose sharply to approximately the accepted 'normal' for men. These authors say 'It is evident, therefore, that the level of haemoglobin in normal women's blood, at any rate in this country, is regulated by their iron intake.... In other words, the accepted "normal" for women's haemoglobin may not be a true normal, but should perhaps be regarded as mildly pathological.' Yudkin (1944) brought forward further evidence to support this view. He estimated the concentration of haemoglobin in the blood of recruits to the Women's Auxiliary Air Force. His findings, when the recruits first joined, were 'normal' for women. At that time the diet in the W.A.A.F. had a high content of iron, $35 \mathrm{mg}$ iron/day. After 6 or more months in the Service on this diet the concentration of haemoglobin in the blood of the women had risen to reach a value acceptable as 'normal' for men. Such findings suggest that the majority of apparently healthy women suffer from some degree of iron-deficiency anaemia.

Fowler \& Barer (194r), however, are sceptical. They believe that administration of iron to patients with true iron-deficiency anaemia will restore the concentration of haemoglobin to its proper level. If there is no true anaemia, merely a low 'normal' concentration of haemoglobin in the blood, administration of iron may well increase this concentration for the time being, but, on ceasing to administer the iron, or even during its continued administration, the concentration will subside to its original low, but in reality natural, level for the individual. According to these authors women have naturally a low 'normal' concentration of haemoglobin in the blood. Quite recently Vahlquist (1950) gave $300-346 \mathrm{mg}$ ferrous iron each day for 8 weeks to twenty-two normal women in the child-bearing age. The concentration of haemoglobin in the 
blood was not increased by this treatment to beyond the concentration in another comparable group of forty women, and, in both instances, the concentration was markedly less than in the blood of men.

During pregnancy the concentration of haemoglobin in the blood of the mother falls still farther. There seems to be an undoubted increase in the total blood volume, but the increase in the volume of the erythrocytes is not so great as the increase in the volume of the plasma. The resulting decrease in the concentration of the haemoglobin is regarded not as an anaemia but as an 'oligocythemic hypervolemia' (Dieckmann \& Wegner, 1934a, $b$; Thomson, McGregor, Hirsheimer, Gibson \& Evans, 1938). Garry \& Stiven (1935-6) and Garry \& Wood (1945-6) review the literature and consider this problem. They evince no little irritation at the lack of reliable information. If this fall in the concentration of haemoglobin in the blood during pregnancy denotes a suboptimal state, then something ought to be done about it. Widdowson (1939) gave very large doses of iron to pregnant women. During this 'therapeutic medication with iron' the 'normal' decrease in the concentration of haemoglobin in the blood was halted, but began again whenever the giving of iron ceased. Widdowson has many pertinent things to say on this problem and gives a most useful bibliography. Undeterred by Widdowson's findings, Benstead \& Theobald (1952) gave very large doses of ferrous sulphate, with some small addition of the sulphates of copper and of manganese, to pregnant women. They were able to abolish the 'normal' fall in the concentration of haemoglobin in the blood. They conclude uncritically that the 'physiological anaemia' of pregnancy is due to an inadequate intake of iron. Be it noted, however, that they, like Widdowson, administered doses of iron that could in no conceivable circumstance find their way normally into the diet of a woman. Fisher \& Biggs (I953), even more recently, also assert that the 'physiological anaemia' of pregnancy is due to an inadequate intake of iron and calmly imply that there is no longer any need for further discussion.

It seems fairly obvious, then, that women, from puberty to menopause, and even to a greater degree during pregnancy, either suffer from a definite degree of irondeficiency anaemia or, as a result of some fundamental femaleness in their constitution, have normally a lower concentration of haemoglobin in their blood than have men. If the latter is the true explanation, then one would expect to find evidence of this same phenomenon in lower animals, where the problem is not complicated by loss of blood at menstruation.

Most unfortunately the available information is meagre and, by modern standards, far from satisfactory. The two sexes of large domesticated animals are rarely treated in the same fashion after they reach maturity. The leader writer of the Veterinary Record (Anonymous, I940), who bewails the lack of normal standards in veterinary haematology, is more than justified in his plaint. Writers of text-books, such as Burnett (1917), Scheunert, Trautmann \& Krzywanek (1939), Dukes (1947) and Marek \& Mócsy (195I), are at one in saying that male animals have a greater concentration of haemoglobin in their blood than have female animals. This attitude seems to go back to 1885 , to the second of Otto's ( 1885 ) three papers on blood. The work is admirable, but the experimental animals, dogs and rabbits, were apparently 
in poor shape. Thus these ex cathedra statements do not carry complete conviction, especially when more recent original papers are consulted.

Workers at the Physiological Institute of Giessen University much later made a series of studies on the blood of animals and of birds (Kuhl, 1919; Fritsch, 1920; Welsch, 1923). Unfortunately they studied only ten of each species, so that, at best, five males were compared with five females. Frequently the information from the two sexes could not properly be compared. Yet it is probably fair to say that, in this painstaking series of observations, no uniform clear evidence was found for an unequivocal influence of sex on the concentration of haemoglobin in the blood. Mayerson (1930) took dogs and bitches of no special breed, bathed, purged and dieted them to achieve standard conditions and then rejected those obviously unfit. He was left with thirty-seven dogs and twenty-three bitches. The mean haemoglobin value for dogs was $12.89 \mathrm{~g} / 100 \mathrm{ml}$. blood, that for the bitches was $13.22 \mathrm{~g} / 100 \mathrm{ml}$. blood.

Dukes \& Schwarte (193I) found the concentration of haemoglobin in the blood of the domestic hen to be markedly less than that in the blood of cocks. Pullets had even lower concentrations. Readings on a few wild birds, however, were higher and then the effect of sex was not obvious. Rosahn, Pearce \& Hu (I934) found that buck rabbits had a significantly greater concentration of haemoglobin in their blood than had virgin doe rabbits of the same litter. Vaulont (1935) found that the mean haemoglobin concentration in the blood of ten female cats was $12.56 \mathrm{~g} / \mathrm{r} 00 \mathrm{ml}$., whereas that in the blood of ten tom cats was $13.07 \mathrm{~g} / 100 \mathrm{ml}$. This difference is not significant statistically. Vaulont also found that the concentration of haemoglobin in the blood of ten geldings was $13.99 \mathrm{~g} / 100 \mathrm{ml}$., the corresponding figures for ten mares being only 12.07 g Hb/roo ml. Holman (1944) examined the blood of $17 \mathrm{I}$ Scottish hill sheep. He says 'no difference due to sex was noticed'.

Wintrobe, Shumacker \& Schmidt (1935-6) carefully studied the blood of considerable numbers of dogs, rabbits and rats. Though they found that there was a greater concentration of haemoglobin in the blood of dogs than in the blood of bitches, they did not confirm the claims of Rosahn et al. (1934) that buck rabbits had a greater concentration of haemoglobin in their blood than had doe rabbits. The mean concentration of haemoglobin in the blood of female rats was slightly greater than that in the blood of male rats. Landsberg (1940) made a careful study of the blood picture in fifty-two cats. Although the number of erythrocytes, the concentration of haemoglobin and the volume of the packed erythrocytes were all greater in the males than in the females, he states that these differences were not significant. For convenience, the more important of the observations on human beings and on lower animals have been brought together in Table $\mathbf{I}$.

It would seem, then, that simple observations on the blood of lower animals give no great support to the idea that sex in itself causes a marked difference between the blood of the male and female creation. At least, there is nothing like the difference accepted as normal between man and woman.

If, owing to faults in our diet, civilized women are really suffering from an intake of iron inadequate to compensate for menstrual loss, it ought to be possible to relieve the condition by adding quite small quantities of iron to the diet. To test this hypothesis 
Table $\mathrm{I}$. Concentration of $\mathrm{Hb}$ in the blood of various mammals

(Values in $\mathrm{g} \mathrm{Hb} / \mathrm{I} 00 \mathrm{ml}$. blood unless otherwise indicated)

Subjects

Adult human beings in U.S.A.

Adult human beings

in England

Adult human beings

in England

Medical students in

in U.S.A.

Medical students and nurses in U.S.A.

Students and nurses

in England

Students in England

Sex (no. in parentheses)

M.

Concentration of $\mathrm{Hb}$

Authority

F.

$12 \cdot 0-17 \cdot 0$, mean $16 \cdot 0$

M. (II8) I $\quad$ 5.85

F. (II6) I3.80

(van Slyke: oxygen capacity)

M. $\quad 14^{\circ} \cdot 17^{\circ} \circ$, mean $15^{\cdot 6}$

F. $\quad 12 \cdot 0-15^{\circ} 5$, mean 13.7

M. (196) $\quad 15 \cdot 8$

F. (106) I3.7

(Authors' acid-haematin method)

M. (86) I6.0 \pm 0.7

F. (IOI) $14.1 \pm 0.6$

(Newcomer haemoglobinometer)

M. (100) I4.5

F. $(100) \quad 13 \cdot 6$

(Gowers-Haldane method)

M. (52) I06.4\% $\% 6.4$

F. (59) $\quad 92.8 \% \pm 6.8$

(Gowers-Haldane method: colour standard of British Standards Institution)

\begin{tabular}{|c|c|c|}
\hline Cats & $\begin{array}{l}\text { M. (10) } \\
\text { F. (10) }\end{array}$ & $\begin{array}{l}13.07 \\
12.56 \\
\text { (Bürker haemoglobinometer) }\end{array}$ \\
\hline Cats & $\begin{array}{l}\text { M. }(25) \\
\text { F. }(27)\end{array}$ & $\begin{array}{l}10.75 \pm 0.400 \\
\text { I0.32 } \pm 0.404 \\
\text { (Newcomer haemoglobinometer) }\end{array}$ \\
\hline Dogs & $\begin{array}{l}\text { M. (22) } \\
\text { F. (10) }\end{array}$ & $\begin{array}{l}15^{*} 1 \\
13^{\circ 9} \\
\text { (Newcomer haemoglobinometer) }\end{array}$ \\
\hline Dogs & $\begin{array}{l}\text { M. }(37) \\
\text { F. }(23)\end{array}$ & $\begin{array}{l}12 \cdot 89 \\
13.22 \\
\text { (Newcomer haemoglobinometer) }\end{array}$ \\
\hline Rabbits & $\begin{array}{l}\text { M. (35) } \\
\text { F. }(26)\end{array}$ & $\begin{array}{l}12 \cdot 9 \\
13 \cdot 4 \\
\text { (Newcomer haemoglobinometer) }\end{array}$ \\
\hline Rabbits & $\begin{array}{l}\text { M. }(4 I) \\
\text { F. }(4 I)\end{array}$ & $\begin{array}{l}72 \cdot 0 \% \pm I \cdot 5 \\
67 \cdot 0 \% \pm I \cdot I \\
\text { (Newcomer haemoglobinometer) }\end{array}$ \\
\hline Rats & $\begin{array}{l}\text { M. }(47) \\
\text { F. }(26)\end{array}$ & $\begin{array}{l}\text { I3.0 } \\
\text { I3.3 } \\
\text { (Newcomer haemoglobinometer) }\end{array}$ \\
\hline
\end{tabular}

Sunderman \& Boerner (I949)

Jenkins \& Don (r933)

Whitby (r95r)

Osgood, Haskins \& Trotman (I93I-2)

Wintrobe (1933)

Price-Jones (193 I)

Medical Research Council: Committee on Haemoglobin Surveys (1945)

Vaulont (1935)

Landsberg (1940)

Wintrobe, Shumacker \& Schmidt (1935-6)

Mayerson (1930)

Wintrobe et al. (1935-6)

Rosahn, Pearce \& Hu (1934)

Wintrobe et al. (1935-6)

the total daily intake of iron ought still to be 'physiological' in magnitude and not 'therapeutic'. Moreover, the administration should continue steadily for some considerable period.

\section{EXPERIMENTAL}

Subjects. We chose the subjects of our surveys and experiments from men and women students of physiology in the University of Glasgow. They thus belonged to a restricted age group, 18-23 years, and their daily activities were as uniform as one is ever likely to encounter in a community containing both men and women. 
No subject was accepted who had had a recent serious illness or a history of disease of the blood at any time. Those who had recently given blood to the Blood Transfusion Service were also excluded. In our second series, I950-I, a blood film was made from all subjects, and, after staining with Leishman's stain, was examined for abnormal cells. No abnormalities were found in the films. All our subjects would be accepted as 'normal' by the usual standards of clinical haematology.

The menstrual cycle is said not to influence the concentration of haemoglobin in the blood, but, as there is known to be a diurnal variation in that concentration, all samples were taken in the afternoon between 2 and 5 p.m.

First series of experiments. The investigation began in modest fashion in the autumn of 1949 as an exercise in the Honours Science Course in Physiology. Initially a simple survey was made of the concentration of haemoglobin in the blood of forty-one women and of twenty-four men. Capillary blood was drawn from the finger. The Medical Research Council grey-wedge photometer was used as a haemoglobinometer. The difference between the sexes was striking.

Through the kindness of Glaxo Laboratories Ltd. we were able to give each woman daily a tablet containing $7 \mathrm{mg}$ iron as ferrous sulphate. Each tablet also had $0 \cdot 13 \mathrm{mg}$ copper and $0.12 \mathrm{mg}$ manganese, both as sulphate.

Five months later, in the spring of $195^{\circ}$, the haemoglobin concentration was estimated in the blood of the same men and women. For various reasons several women had dropped out of the experiment in the interval. Thirty-five women and twenty-four men remained. The results, as will be seen below, were equivocal. But they were sufficiently suggestive to make us decide to embark on a much more ambitious project. In certain respects the design of this second undertaking differed materially from that of the initial experiment just described.

Second series of experiments. Venous blood was withdrawn from an antecubital vein, care being taken to avoid stasis. Clotting was prevented by the use of $4 \mathrm{mg}$ solid potassium oxalate and $6 \mathrm{mg}$ solid ammonium oxalate for each $10 \mathrm{ml}$. blood.

Estimations of the concentration of haemoglobin were carried out on a $\mathbf{I}$ in 200 dilution of the blood in a $0.04 \%$ solution of ammonia in distilled water (Szigeti, 1940). In such a solution almost all the haemoglobin is in the form of oxyhaemoglobin. The concentration of the haemoglobin was found by a photoelectric absorptiometer. This instrument had previously been calibrated against solutions of oxyhaemoglobin from bloods whose haemoglobin content had been estimated as alkaline haematin by means of the Gibson-Harrison standard solution (Gibson \& Harrison, 1945). Estimations were carried out in triplicate on two separate dilutions of each sample of venous blood. The pipettes used to make the dilutions were calibrated and the appropriate correction factors applied.

The first estimations were made in the autumn of 1950 . The subjects were then divided into six groups, three of women, three of men. By stratified random allocation it was ensured that each group had comparable numbers of subjects with high, with medium and with low concentrations of haemoglobin in the blood. Initially there were eighteen subjects in each of the three male groups and eighteen, nineteen and eighteen subjects in the three female groups. In all, rog subjects embarked on the experiment. 
Glaxo Laboratories Ltd. were good enough to give us a further large number of tablets to issue to the students. One-third of the tablets had $28 \mathrm{mg}$ iron, $0.52 \mathrm{mg}$ copper and $0.47 \mathrm{mg}$ manganese as ferrous sulphate, copper sulphate and manganese sulphate. Another third had $14 \mathrm{mg}$ iron, $0.26 \mathrm{mg}$ copper and $0.24 \mathrm{mg}$ manganese. The final third was a placebo, devoid of these elements. All the tablets were exactly similar in appearance and could be distinguished only by a code letter on the container. Only one member of this department had the key to the composition of the tablets. Periodically he took a sample of the tablets being issued to the subjects and checked chemically the iron content against his key. He was not otherwise concerned with the experiment. Thus, those issuing the tablets, drawing the blood and making the estimations of the concentration of haemoglobin in the blood of the subjects had knowledge neither of the iron content of the tablets nor of the treatment being given.

Each man in one of the male groups, and each woman in one of the female groups, received sixty to seventy tablets belonging to a batch with the same code letter. Men in a second male group, and women in a second female group, received tablets belonging to another batch. The third group of men and the third group of women received tablets of the third batch. All were told to take one tablet each day after a meal. The subjects reported at intervals of 2 months to receive a new issue of tablets from the appropriate batch. We thus had the opportunity to check that the students were co-operating and taking their tablets. Not until the end of the experiment, when the estimations of the concentration of haemoglobin in the blood had all been completed, did we learn from the key which groups had received the tablets with $28 \mathrm{mg}$ iron, which the tablets with $14 \mathrm{mg}$ iron and which the placebos.

Estimations of the haemoglobin concentration were finally made in November 195I, I2 months after the beginning of the experiment. Unfortunately, in the interval, our photoelectric absorptiometer developed a fault and had to be returned to the makers for overhaul. It was recalibrated before use in November I95I. We excluded from the final series all students who during the 12 months had suffered from a serious illness or who had received massive chemotherapy. Those who admitted that they had failed to take the tablets for a continuous period exceeding I week were also excluded. As a result, the three male groups were reduced to thirteen, fifteen and twelve subjects, the three female groups to ten, sixteen and fourteen. Eighty out of the original rog stayed the course.

\section{RESULTS}

\section{The 'normal' concentration of haemoglobin, in the blood of men and women students}

First series of experiments, October 1949, twenty-four men, forty-one women. The histograms of Fig. I show clearly that these healthy young men and women form two distinct groups with, however, a considerable overlap. The mean values, the standard deviations and the standard errors of the means are shown in Table 2. The difference between the mean values for the men and for the women was statistically highly significant, $P<0.001$. 
Second series of experiments, November 1950 , fifty-four men, fifty-five women. The histograms of Fig. 2 show once more the marked difference between the two sexes. The difference between the means is of the same order as that in the 1949 survey (Table 2 ) and is once more highly significant, $P<0 \cdot 001$.

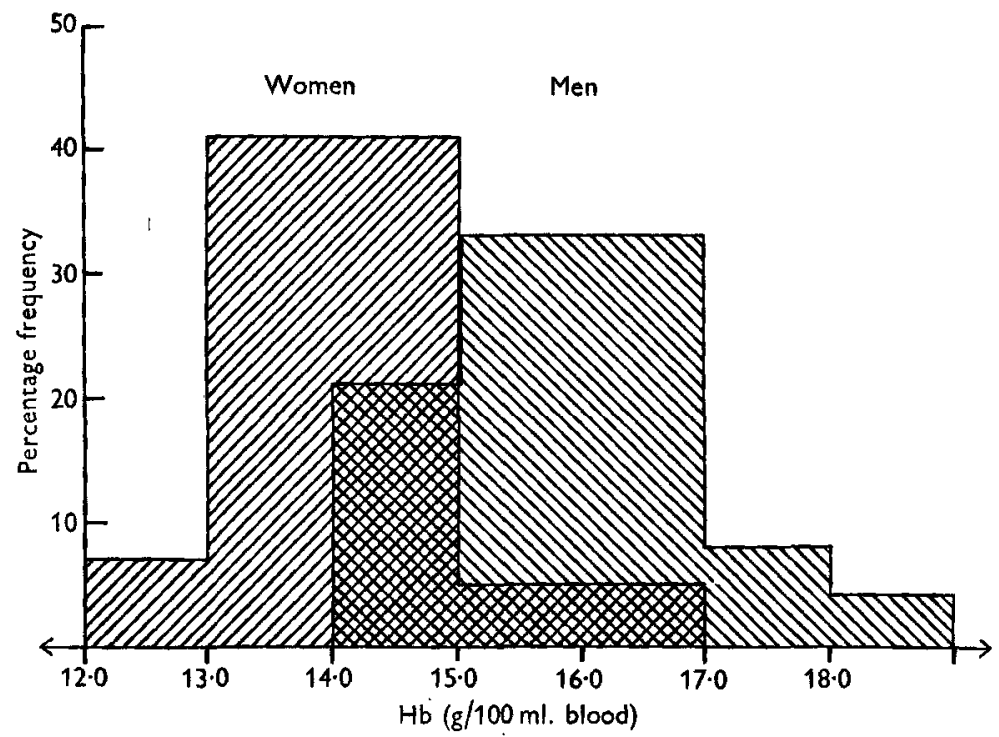

Fig. I. First series of experiments: concentration of haemoglobin in the blood of twenty-four men and forty-one women students: initial readings, October 1949.

Table 2. First and second series of experiments. Observed initial concentrations of $\mathrm{Hb}$ in the blood of the men and women students

\begin{tabular}{|c|c|c|c|c|}
\hline Series & Sex & $\begin{array}{l}\text { No. of } \\
\text { subjects }\end{array}$ & 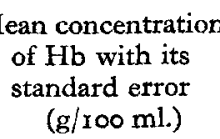 & $\begin{array}{l}\text { Standard } \\
\text { deviation }\end{array}$ \\
\hline $\begin{array}{l}\text { First } \\
\text { (October 1949) }\end{array}$ & $\begin{array}{l}\text { M. } \\
\text { F. }\end{array}$ & $\begin{array}{l}24 \\
4 I\end{array}$ & $\begin{array}{l}15.92 \pm 0.23 \\
14.02 \pm 0.13\end{array}$ & $\begin{array}{l}\text { I.II } \\
0.86\end{array}$ \\
\hline $\begin{array}{l}\text { Second } \\
\text { (November 1950) }\end{array}$ & $\begin{array}{l}\text { M. } \\
\text { F. }\end{array}$ & $\begin{array}{l}54 \\
55\end{array}$ & $\begin{array}{l}16.21 \pm 0.11 \\
14.59 \pm 0.10\end{array}$ & $\begin{array}{l}0.81 \\
0.76\end{array}$ \\
\hline
\end{tabular}

The effect of giving small doses of ferrous sulphate by mouth

First series of experiments, October 1949-May 1950, daily administration of $7 \mathrm{mg}$ iron as ferrous sulphate to thirty-five women. As can be seen from Table 3 , the mean value for the concentration of haemoglobin in the men increased very slightly from October to May. The increase in the women was greater and statistically significant, $P<0.01$; the increase in the men was not statistically significant. However, the increase in the women was not significantly greater than that in the men. Thus, in this portion of the experiment, the evidence was insufficient to show that administration of iron to the women was solely responsible for the observed increase in the concentration of haemoglobin in their blood, and the difference between the concentrations of haemoglobin in the blood of the men and women was essentially unchanged. 


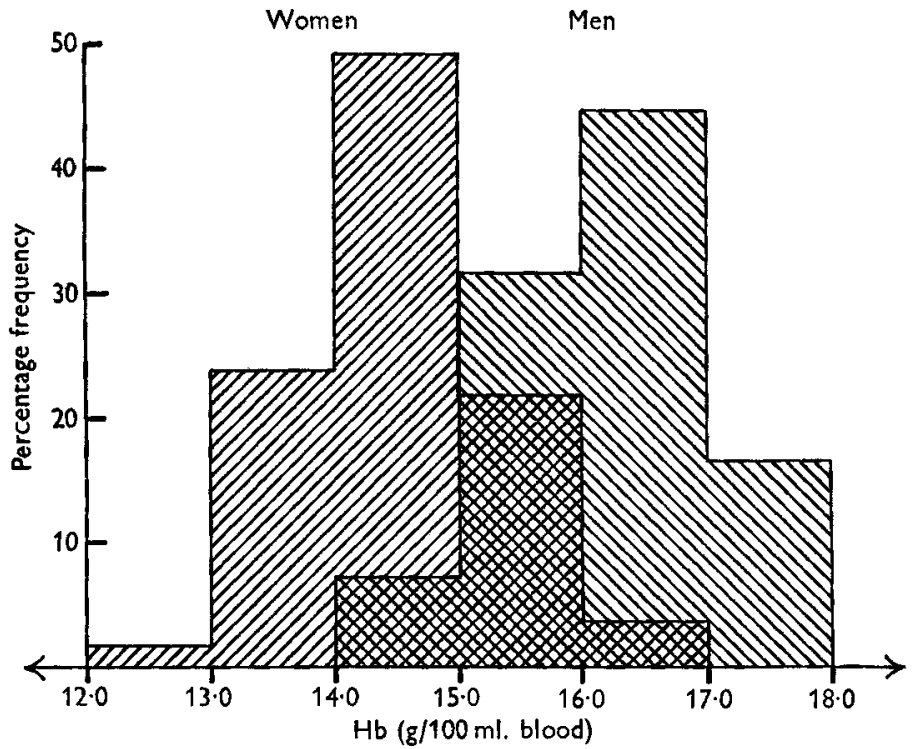

Fig. 2. Second series of experiments: concentration of haemoglobin in the blood of fifty-four men and fifty-five women students: initial readings, November 1950.

Table 3. First series of experiments, October 1949-May 1950. Effect of daily administration of a supplement of $7 \mathrm{mg}$ iron to the women. The men had no supplement

\begin{tabular}{|c|c|c|}
\hline Sex & $\begin{array}{c}\text { No. of } \\
\text { subjects }\end{array}$ & Date \\
\hline M. & 24 & $\begin{array}{l}\text { October } 1949 \\
\text { May } 1950\end{array}$ \\
\hline F. & 35 & $\begin{array}{l}\text { October } 1949 \\
\text { May 1950 }\end{array}$ \\
\hline
\end{tabular}

Mean concentration
of $\mathrm{Hb}$
(g/roo ml.)
15.92
16.07
13.93
14.35

Mean change in concentration of $\mathrm{Hb}$ with its standard error Standard $(\mathrm{g} / \mathrm{r} 00 \mathrm{ml}$.) deviation $+0.15 \pm 0.17 \quad 0.83$$$
+0.42 \pm 0.15 \quad 0.87
$$

Second series of experiments, November 1950-November 195 I, daily administration of 14 or of $28 \mathrm{mg}$ iron or of a placebo to forty men and forty women. The initial grand mean for the forty men was $16 \cdot 176 \mathrm{~g} \mathrm{Hb} / 100 \mathrm{ml}$. blood and that for the forty women was 14.593, showing a sex difference of $1 \cdot 5^{8}$. The results for the individual groups are shown in Table 4. In every group the mean concentrations of $\mathrm{Hb}$ in the blood decreased from November $195^{\circ}$ to November 1951. The decreases in the means were greatest in the control groups. Thus, relative to the control groups, all groups receiving iron showed a small increase. The response did not differ significantly between the two sexes or between the two treated groups, but the average response in these two groups differed from the average response in the controls by $0.207 \pm 0.102 \mathrm{~g} \mathrm{Hb} / 100 \mathrm{ml}$. blood, $P<0.05$.

Table 5 gives the coefficient of the regression of final haemoglobin concentration on initial haemoglobin concentration for each group. In so far as the slopes of the regression lines for the treated groups are less than those for the control groups they suggest that, within each treated group, the response was greater the lower the initial 
Table 4. Second series of experiments, November 1950-November 1951. Effect of daily administration of a supplement of 14 or of $28 \mathrm{mg}$ iron or of a placebo to forty men and forty women

\begin{tabular}{|c|c|c|c|c|c|}
\hline Sex & $\begin{array}{l}\text { No. of } \\
\text { subjects }\end{array}$ & Date & $\begin{array}{c}\text { Mean concentration } \\
\text { of } \mathrm{Hb} \\
\text { (g/100 ml.) }\end{array}$ & $\begin{array}{c}\text { Mean change in } \\
\text { concentration of } \mathbf{H b} \\
\text { with its standard error } \\
(\mathrm{g} / \mathrm{I} 00 \mathrm{ml} .)\end{array}$ & $\begin{array}{l}\text { Standard } \\
\text { deviation }\end{array}$ \\
\hline \multicolumn{6}{|c|}{ Control groups receiving no supplement of iron } \\
\hline M. & 15 & $\begin{array}{l}\text { November } 195^{\circ} \\
\text { November } 195 \mathrm{I}\end{array}$ & $\begin{array}{l}16 \cdot 26 \\
15 \cdot 72\end{array}$ & $-0.545 \pm 0.13$ & 0.48 \\
\hline F. & I6 & $\begin{array}{l}\text { November } 195^{\circ} \\
\text { November I95I }\end{array}$ & $\begin{array}{l}14 \cdot 69 \\
14 \cdot 14\end{array}$ & $-0.551 \pm 0.09$ & 0.38 \\
\hline \multicolumn{6}{|c|}{ Treated groups receiving a supplement of $14 \mathrm{mg}$ iron daily } \\
\hline M. & 13 & $\begin{array}{l}\text { November } 1950 \\
\text { November } 195 \mathrm{I}\end{array}$ & $\begin{array}{l}\times 6 \cdot 08 \\
15.71\end{array}$ & $-0.367 \pm 0.09$ & 0.32 \\
\hline F. & 10 & $\begin{array}{l}\text { November } 195^{\circ} \\
\text { November I95 I }\end{array}$ & $\begin{array}{l}14^{\cdot} 5^{8} \\
14^{\cdot 25}\end{array}$ & $-0.329 \pm 0.11$ & 0.36 \\
\hline \multicolumn{6}{|c|}{ Treated groups receiving a supplement of $28 \mathrm{mg}$ iron daily } \\
\hline M. & 12 & $\begin{array}{l}\text { November 1950 } \\
\text { November } 195 \mathrm{I}\end{array}$ & $\begin{array}{l}16 \cdot 17 \\
15 \cdot 84\end{array}$ & $-0.33^{8} \pm 0.15$ & 0.53 \\
\hline F. & 14 & $\begin{array}{l}\text { November } 195^{\circ} \\
\text { November I } 95 \text { I }\end{array}$ & $\begin{array}{l}14 \cdot 49 \\
14 \cdot 16\end{array}$ & $-0.327 \pm 0.16$ & 0.60 \\
\hline
\end{tabular}

concentration of haemoglobin. Analysis of the variance of the coefficients shows that the difference between the treated groups and the control groups was significant $(0.05>P>0.01)$, the difference between treatments just fails to reach significance $(0 \cdot 1>P>0.05)$ and the sex difference was not significant. Thus for each treatment level the regressions for men and for women did not differ significantly from two parallel lines and the significance of the distance between each pair of parallel lines can be investigated. For the combined treated groups the distance was $0.53 \pm 0.18 \mathrm{~g}$ $\mathrm{Hb} / \mathrm{roo} \mathrm{ml}$. and so was highly significant $(0.0 \mathrm{r}>P>0.00 \mathrm{r})$. Thus the response of the women was significantly less than that of the men for any given initial concentration of haemoglobin. These two regression lines along with the joint regression line of the two control groups (which is shown separately in Fig. 3), are shown in Fig. 4. All three lines have been adjusted for attenuation.

Table 5. Second series of experiments, November 1950-November 195r. Effect of daily administration of a supplement of $\mathrm{I} 4$ or of $28 \mathrm{mg}$ iron or of a placebo to forty men and forty women: the gradients, $b$, of the regressions of the final concentrations of $\mathrm{Hb}(y)$ on the initial concentrations of $\mathrm{Hb}(x)$

Sex $b$

Control groups receiving no supplement of iron

$\begin{array}{ll}\text { M. } & 0.90 \pm 0.13 \\ \text { F. } & 0.90 \pm 0.12\end{array}$

Treated groups receiving a supplement of $14 \mathrm{mg}$ iron daily

M. $\quad 0.72 \pm 0.16$

F. $\quad 0.62 \pm 0.26\left(0.97 \pm 0.19^{*}\right)$

Treated groups receiving a supplement of $28 \mathrm{mg}$ iron daily

M. $\quad 0.61 \pm 0.16$

F. $\quad 0.37 \pm 0.17$

* Including one exceptional result. 
Vol. 8

For each sex the response was greater the lower the initial value for the haemoglobin concentration. Conversely for each sex there was a value for the initial haemoglobin concentration towards the upper end of the range for that sex for which on average there was no change relative to the control groups. These 'saturation values' were quite different for the two sexes and this difference appears to be the one essential sex difference in response.

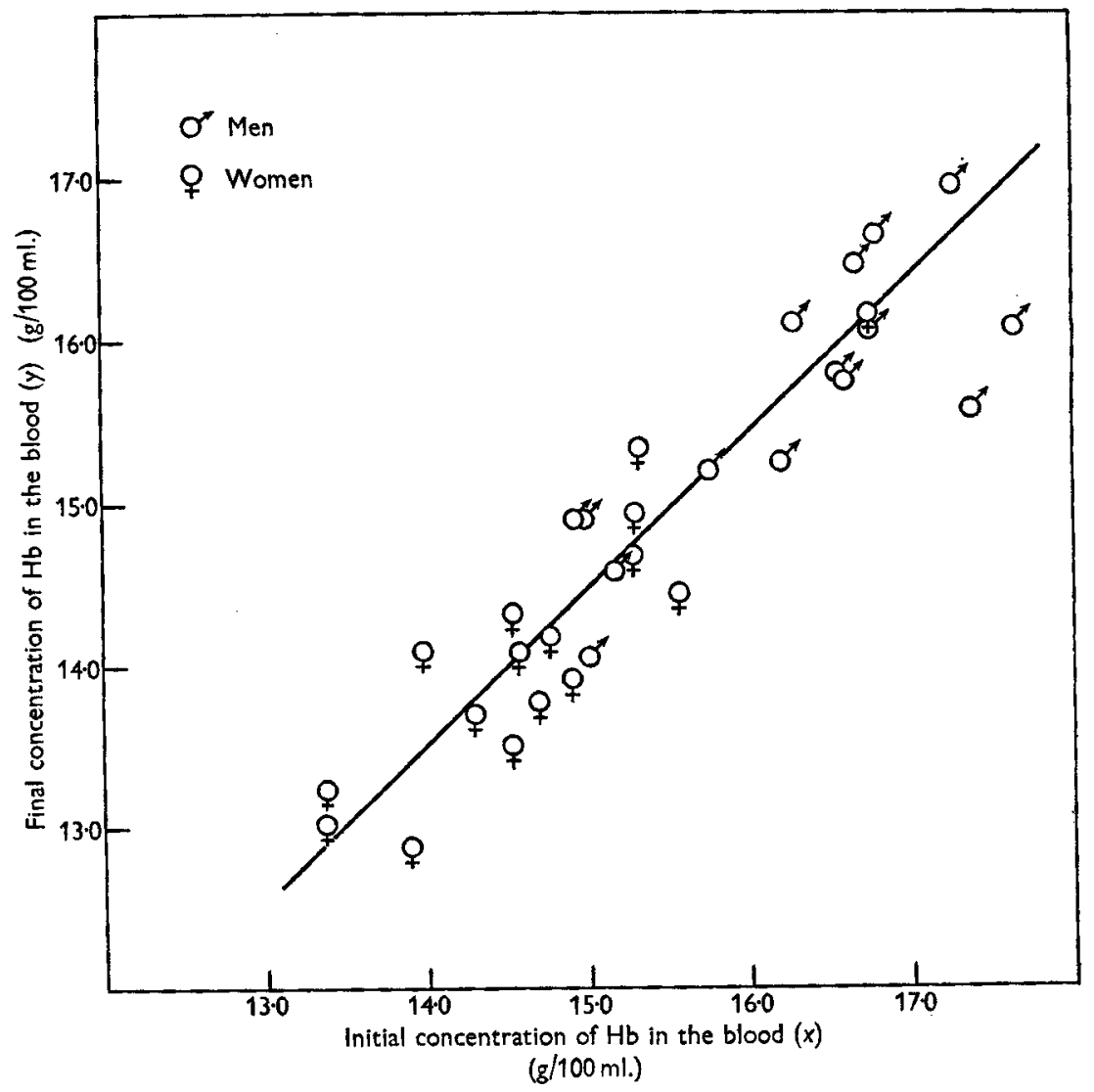

Fig. 3. Second series of experiments: scatter diagram of the initial and final concentrations of haemoglobin in the blood of the men and women in the control groups who received no supplement of iron. The straight line is the adjusted regression of the initial on the final concentration of haemoglobin.

\section{DISCUSSION}

Although there is much room for further careful observation, it is probably true to say that the influence of sex on the concentration of haemoglobin in the blood does not appear to be so marked in lower mammals as in human beings. Be it noted that the adult female of these lower mammals does not have a periodical loss of blood. Until the age of puberty and the onset of menstruation the concentration of haemoglobin in the blood of boys and girls is the same. There is a not inconsiderable overlap in the frequency distributions of the concentrations of haemoglobin in the blood of 
adult men and women (Figs. I and 2). Such facts formidably support the view that the concentration of haemoglobin in the blood of women ought not to be less than the concentration in the blood of men. Since women suffer a monthly loss of blood and men do not, is it possible that the usual intake of iron in our common food is insufficient for the needs of women? Frank anaemia is more common in women than in men and is usually attributed to an inadequate intake of iron. And such irondeficiency anaemias undoubtedly respond to therapeutic administration of iron.

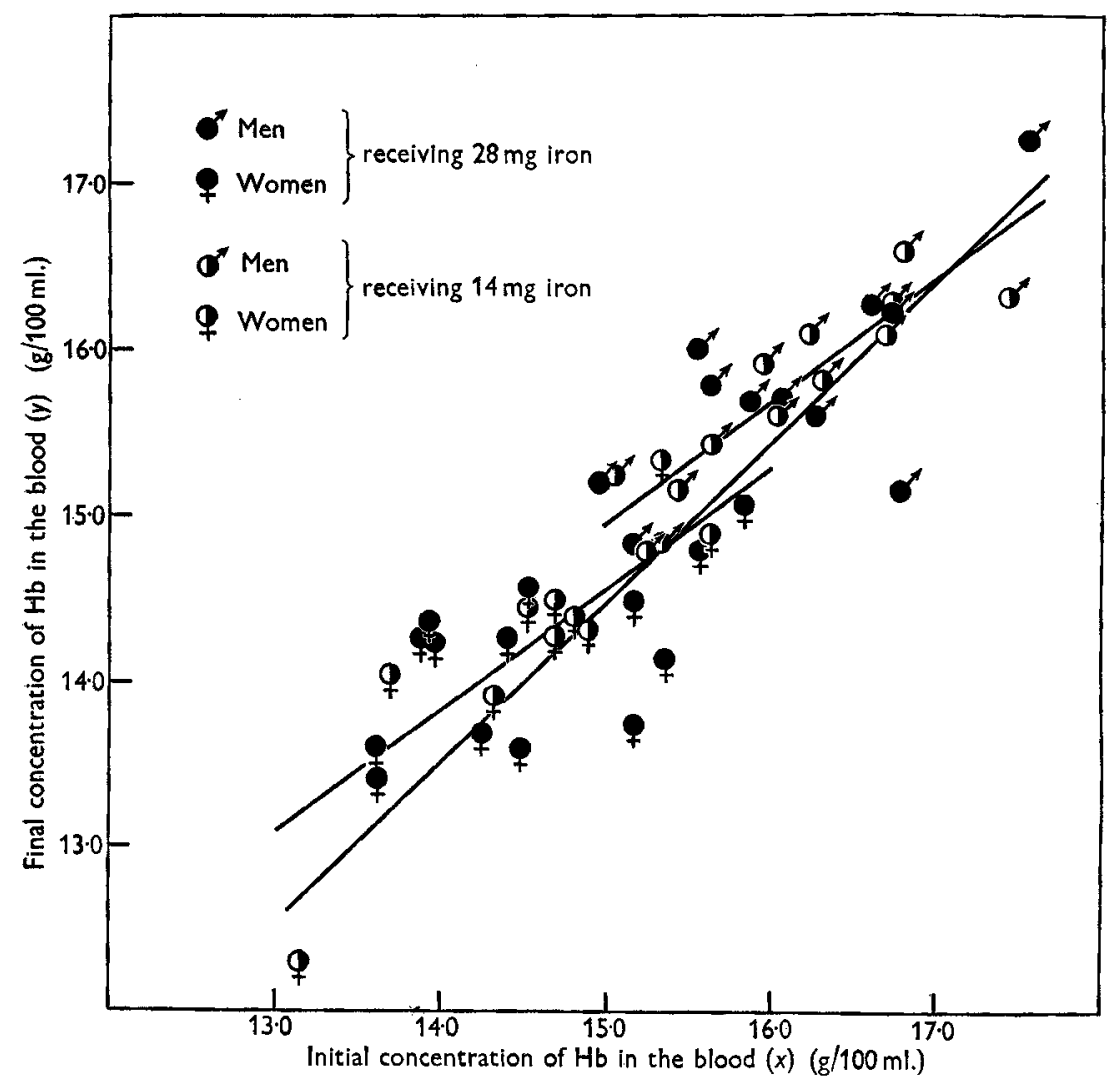

Fig. 4. Second series of experiments: scatter diagram of the initial and final concentrations of haemoglobin in the blood of the men and women in the treated groups. These received a supplement of either 14 or $28 \mathrm{mg}$ iron. The two short straight lines are the adjusted regressions for all the men and all the women receiving a supplement of iron. The long straight line is the adjusted regression of both the control groups as shown in Fig. 3 .

We made no attempt to find the actual daily intake of iron by our subjects in their food. However, close questioning about the nature of their diets revealed no grounds for suspecting an intake of iron below the usual for urban men and women. The groups receiving $\mathrm{I} 4 \mathrm{mg}$ of additional iron probably had a total daily intake of between 20 and $30 \mathrm{mg}$. Those receiving $28 \mathrm{mg}$ of additional iron may have had a total intake of the order of $40 \mathrm{mg}$ each day. It would require a revolution in customary dietary habits to achieve a daily intake more than this from our civilized foods.

In the second series the mean concentration of haemoglobin in the blood decreased 
in all groups from November $195^{\circ}$ to November 195I. Between these two dates our photoelectric absorptiometer had to be overhauled and recalibrated. The observed decrease may then not have been real. However, from the final readings alone, it is abundantly clear that daily administration of small doses of an iron salt did not lessen, let alone abolish, the difference initially observed between the sexes. On the other hand, the treated groups that received iron did not show such a marked decrease as the control groups. This 'increase' relative to the control groups occurred in men and women alike. Only those who had initially a high concentration of haemoglobin in the blood failed to show this 'increase' when they received a modest supplement of iron in the food. We may say, then, that the subjects who showed no increase were initially at their saturation concentration of haemoglobin. This 'saturation value' was less for women than for men. The farther individuals were below this 'saturation value', the greater the increase they showed. The two sexes behaved in similar fashion. If the supplements of iron we gave really restored the intake to the true physiological requirement for mankind, then the majority of our subjects, both men and women, had a slight degree of iron-deficiency anaemia. We would emphasize, however, that the 'saturation values' found in the present experiment must be regarded as only approximate. However this may be, it does seem clear that the difference between the sexes cannot be attributed to an inadequate intake of iron on the part of the women. The cause must be looked for elsewhere.

There is some evidence that women who have given blood for blood transfusion regenerate their erythrocytes and haemoglobin at a slower rate than do men. Administration of iron does not abolish this sex difference (Fowler \& Barer, 1942). Eunuchs are said to have a lower concentration of haemoglobin, and fewer red corpuscles, in their blood than normal men. The normal concentration for intact men can be restored by giving testosterone. Removal of the ovaries from women, on the other hand, increases the concentration of haemoglobin in the blood and subsequent administration of oestradiol then lowers the concentration of haemoglobin to the usual female level (Daughaday, Williams \& Daland, 1948; McCullagh \& Jones, 194I, 1942). Vahlquist (1950) made very pertinent observations on twenty women, under 45 years of age, from whom the uterus had been removed. These women no longer lost iron during menstruation but the ovaries were still active. In spite of the cessation of the monthly loss of iron the concentration of haemoglobin in the blood of these women did not increase beyond the concentration found in forty comparable intact women, and in both groups of women the concentration of haemoglobin in the blood was markedly less than the concentration in the blood of forty men.

Observations on lower mammals and on birds also suggest that oestrogens depress the concentration of haemoglobin in the blood whereas androgens enhance the concentration (Domm, Taber \& Davis, I943; Gordon \& Charipper, 1946-7; Steinglass, Gordon \& Charipper, I94I; Taber, Davis \& Domm, 1942-3; Vollmer \& Gordon, 194r). It is said that the sex hormones influence the activity of the red bone-marrow, oestrogens inhibiting, androgens stimulating. After haemorrhage male rats have more rapid regeneration of erythrocytes than do female rats (Finkelstein, Gordon \& Charipper, 1944). 
It must be confessed that some of the work on lower animals fails to carry conviction, yet these findings do not conflict with our complete failure, by administration of iron over a long period, to lessen the gap between the concentration of haemoglobin in the blood of men and women. There seems to be something in the constitution of the female that prevents attainment of the same blood picture as in the male. Although said in quite another connexion, we cannot do better than quote the wise words of Braude, Kon \& Porter (1953): 'This could be more certainly assessed if workers would publish their negative findings with the same enthusiasm as they show in publishing observations of spectacular response'.

Should one conclude, then, that the female is at a biological disadvantage? The experience of mankind gives no warrant for any such belief. It must be remembered that we estimated only the concentration of haemoglobin in the blood. It is by no means certain that the decrease in the concentration of haemoglobin in the blood of pregnant women is indicative of a suboptimal state (Garry \& Stiven, 1935-6; Garry \& Wood, 1945-6). We have no right to conclude from our findings that the blood of the woman in her body is functionally less efficient than the blood of the man in his body.

\section{SUMMARY}

I. The literature dealing with the concentrations of haemoglobin in the blood of adult human beings and of mature lower mammals is reviewed. The concentration of haemoglobin in the blood of adult civilized women is known to be less than the concentration in the blood of men. Evidence for this sex difference is by no means well established in lower mammals.

2. Two series of observations were made on the concentration of haemoglobin in the blood of men and of women university students. In age and general environment the circumstances of these men and women were similar.

3. Initially, although there was some overlap in the distribution, there was a statistically highly significant difference, in both series, between the means of the concentrations of haemoglobin in the bloods of the two sexes. In the first series the mean value for the twenty-four men was $15.92 \pm 0.23 \mathrm{~g} \mathrm{Hb} / \mathrm{roO} \mathrm{ml}$. blood, the corresponding figure for the forty-one women was $14 \cdot 20 \pm 0.13$. In the second series the mean value in fifty-four men was $16 \cdot 21 \pm 0.11$ and that in fifty-five women was $14 \cdot 59 \pm 0 \cdot 10$.

4. In the first series the women received daily a supplement of $7 \mathrm{mg}$ iron for a period of 5 months. The men received no additional iron. Although the mean concentration of haemoglobin in the blood of the women increased slightly, so also did that in the blood of the men. There was then no satisfactory evidence that giving a small dose of iron increased the concentration of haemoglobin in the blood of the women.

5. In the second series the men and women were divided each into three groups. One group of the men and one group of the women received daily, in the form of a tablet, a supplement of $28 \mathrm{mg}$ iron as ferrous sulphate. Copper and manganese, also as the sulphate, were present in the tablet to the extent of 0.52 and $0.47 \mathrm{mg}$, respectively. Two more groups, one of men and one of women, received a supplement of $14 \mathrm{mg}$ iron with $0.26 \mathrm{mg}$ copper and $0.24 \mathrm{mg}$ manganese. The remaining two 
groups acted as controls, the subjects each receiving a placebo indistinguishable from the tablets containing iron. The administration of the tablets continued for $I$ year.

6. At the end of the year the difference between the mean concentrations of haemoglobin in the bloods of the men and of the women was still of the order of $\mathrm{I} .5 \mathrm{~g}$ $\mathrm{Hb} / \mathrm{roO} \mathrm{ml}$. blood: administration of iron had signally failed to diminish the difference in concentration of haemoglobin in the blood of the two sexes. It is difficult, then, to attribute this difference to an inadequate intake of iron by the women.

7. The groups of men and women that received iron showed, relative to the control groups, an increase in the concentration of haemoglobin in the blood.

8. In both sexes the lower the initial concentration of haemoglobin in the blood the greater was the response to the administration of iron.

First and foremost we are in the debt of the Glasgow University undergraduates who cheerfully submitted themselves to our importunities and ministrations and cast a not uncritical eye on our results.

To Glaxo Laboratories Ltd. go our sincere thanks for a most generous supply of tablets to issue to the subjects of this experiment and to Mr A. L. Bacharach for his good offices in this regard.

Dr S. D. Morrison kindly kept a running check on the composition of the tablets issued, Dr Beck helped us in the early stages of the work and Mr Callander drew the figures.

From the Rankin Medical Research Fund of the University of Glasgow we gratefully received financial help.

\section{REFERENCES}

Anonymous (1940). Vet. Rec. 52, 165.

Balfour, W. M., Hahn, P. F., Bale, W. F., Pommerenke, W. T. \& Whipple, G. H. (1942). F. exp. Med. 76,15 .

Barer, A. P. \& Fowler, W. M. (1936). Amer. F. Obstet. Gynec. 31, 979.

Benstead, N. \& Theobald, G. W. (1952). Brit. med. F. i, 407.

Berry, W. T. C., Cowin, P. J. \& Magee, H. E. (1952). Brit. med. F. i, 4 Io.

Braude, R., Kon, S. K. \& Porter, J. W. G. (1953). Nutr. Abstr. Rev. 23, 473.

Burnett, S. H. (1917). The Clinical Pathology of the Blood of Domesticated Animals, and ed. New York: The Macmillan Company.

Daughaday, W. H., Williams, R. H. \& Daland, G. A. (1948). Blood, 3, 1342.

Davidson, L. S. P., Donaldson, G. M. M., Lindsay, S. T. \& McSorley, J. G. (1943). Brit. med. F. ii, 95.

Davidson, L. S. P., Fullerton, H. W., Howie, J. W., Croll, J. M., Orr, J. B. \& Godden, W. (I933). Brit. med. $\%$, i, 685 .

Davies, G., Levin, B. \& Oberholzer, V. G. (1952). F. clin. Path. 5, 312.

Dieckmann, W. J. \& Wegner, C. R. (1934a). Arch. intern. Med. 53, 7I.

Dieckmann, W. J. \& Wegner, C. R. (1934b). Arch. intern. Med. 53, I88.

Domm, L. V., Taber, E. \& Davis, D. E. (1943). Proc. Soc. exp. Biol., N.Y., 52, 49.

Dukes, H. H. (1947). The Physiology of Domestic Animals, 6th ed. New York: Comstock Publishing Co. Inc.

Dukes, H. H. \& Schwarte, L. H. (193I). Amer. \%. Physiol. 96, 89.

Finkelstein, G., Gordon, A. S. \& Charipper, H. A. (1944). Endocrinology, 35, 267.

Fisher, M. \& Biggs, R. (1953). Brit. med. F. i, 402.

Fowler, W. M. \& Barer, A. P. (I94I). Amer. Y. med. Sci. zor, 642.

Fowler, W. M. \& Barer, A. P. (1942). Э. Amer. med. Ass. I18, 42 I.

Fritsch, G. (1920). Pflüg. Arch. ges. Physiol. 18r, 78.

Garry, R. C. \& Stiven, D. (1935-6). Nutr. Abstr. Rev. 5, 855.

Garry, R. C. \& Wood, H. O. (1945-6). Nutr. Abstr. Rev. 15, 59 r. 
Gibson, Q. H. \& Harrison, D. C. (1945). Biochem. F. 39, 490.

Gillett, L. H., Wheeler, L. \& Yates, A. B. (1918-19). Amer. F. Physiol. 47, 25.

Gordon, A. S. \& Charipper, H. A. (1946-7). Ann. N.Y. Acad. Sci. 48, 615.

Holman, H. H. (1944). F. comp. Path. 54, 26.

Jenkins, C. E. \& Don, C. S. D. (1933). F. Hyg., Camb., 33, 36.

Kuhl, P. (19r9). Pflüg. Arch. ges. Physiol. 176, 263.

Landsberg, J. W. (1940). Folia haemat., Lpz., 64, 169.

McCullagh, E. P. \& Jones, R. (r941). Cleveland Clin. Quart. 8, 79.

McCullagh, E. P. \& Jones, R. (×942). F. clin. Endocrin. 2, 243.

Marek, J. \& Mócsy, J. (I95I). Lehrbuch der klinischen Diagnostik der inneren Krankheiten der Haustiere. Jena: Fischer.

Mayerson, H. S. (1930). Anat. Rec. 47, 239.

Medical Research Council: Committee on Haemoglobin Surveys (1945). Spec. Rep. Ser. med. Res. Coun., Lond., no. 252.

Milam, D. F. \& Muench, H. (1946). F. Lab. clin. Med. 31, 878.

Ohlson, M. A. \& Daum, K. (1935). F. Nutr. 9, 75.

Osgood, E. E. (1926). Arch. intern. Med. 37, 685.

Osgood, E. E., Haskins, H. D. \& Trotman, F. E. (1931-2). J. Lab. clin. Med. r7, 859.

Otto, J. G. (1885). Pflüg. Arch. ges. Physiol. 36, 36.

Price-Jones, C. (1931). F. Path. Bact. 34, 779.

Rosahn, P. D., Pearce, L. \& Hu, C. K. (1934). F. exp. Med. 6o, 687.

Scheunert, A., Trautmann, A. \& Krzywanek, F. W. (1939). Lehrbuch der Veterinärphysiologie. Berlin: Paul Parey.

Steinglass, P., Gordon, A. S. \& Charipper, H. A. (1941). Proc. Soc. exp. Biol., N.Y., 48, 169.

Sunderman, F. W. \& Boerner, F. (1949). Normal Values in Clinical Medicine. London: W. B. Saunders Company.

Szigeti, B. (1940). Biochem. F. 34, 1460.

Taber, E., Davis, D. E. \& Domm, L. V. (1942-3). Amer. F. Physiol. 138, 479.

Thomson, K. J., McGregor, M., Hirsheimer, A., Gibson, J. G. Jr. \& Evans, W. A. Jr. (1938). Amer. Э. Obstet. Gynec. 38, 48 .

Vahlquist, B. (1950). Blood, 5, 874.

Vaulont, H. (1935). Z. Biol. 96, 241.

Vollmer, E. P. \& Gordon, A. S. (I94I). Endocrinology, 29, 828.

Welsch, W. (1923). Pflüg. Arch. ges. Physiol. 198, 37.

Whitby, L. (r951). Lancet, 260, I3I.

Widdowson, E. M. (1939). Lancet, 237, 640.

Widdowson, E. M. \& McCance, R. A. (1936). F. Hyg., Camb., 36, I3.

Williamson, C. S. (1916). Arch. intern. Med. 18, 505.

Wintrobe, M. M. (1933). Fohns Hopk. Hosp. Bull. 53, I I8.

Wintrobe, M. M., Shumacker, H. B. Jr. \& Schmidt, W. J. (1935-6). Amer. F. Physiol. Ir4, 502.

Yudkin, S. (1944). Brit. med. F. ii, 403 . 